\title{
GROUNDWATER QUALITY ASSESSMENT OF QUATERNARY AQUIFER, WADI QENA BASIN, EASTERN DESERT, EGYPT.
}

\author{
Samah Mahmoud Morsy \\ Faculty of Science, Ain Shams University, Cairo, Egypt
}

\begin{abstract}
The present study focused on assessing the quality of groundwater of the Quaternary aquifer in Wadi Qena Basin to deduce its suitability for different purposes according to the World Health Organization and Egyptian standards. Groundwater samples are collected from twenty three water points and analyzed to determine physicochemical parameters. Two effective techniques are used to develop the assessment of groundwater quality in the concerned aquifer; Groundwater Quality Information Mapping and Water Quality Index Estimation and mapping. Geographic Information System (GIS) was used to establish the integration of attribute data base and spatial data base for the studied aquifer. Therefore, by using GIS Tools; spatial interpolation Inverse Distance Weighted (IDW) as well as Reclassify and Weight Overlay methods are carried out to generate Water Quality Information map for the concerned aquifer. The Water Quality Index (WQI) estimation and mapping is used to generate WQI map by using GIS spatial IDW method. The obtained maps delineated the groundwater in studied aquifer into zones according to its suitability for human consumption. These maps revealed congruent results, where most of groundwater in this aquifer exists in the Not-suitable zone for drinking purposes however; it is suitable for irrigation purposes. The best sites for groundwater extractions from the Quaternary aquifer in Wadi Qena Basin are detected at the eastern side of the study area; where the groundwater exists in the Potable zone which suitable for drinking and human consumption. The spatial data base constructed in GIS technique is helpful for monitoring and managing groundwater quality of the Quaternary aquifer in the study area.
\end{abstract}

Keywords: Groundwater quality assessment, GIS, Water Quality Index (WQI), Wadi Qena Basi

\section{INTRODUCTION}

Groundwater in Wadi Qena Basin is available from different water bearing formations, occurring under different hydrogeologic conditions. These aquifers from the younger to the older are: Alluvium aquifer (Quaternary), Carbonate and sandstone aquifer (Eocene-Pliocene), Nubia sandstone aquifer (TuronianSantonian) and Fractured basement complex aquifer (Precambrian) (Hussien, 2017). These hydrogeologic features control the groundwater occurrence, movement and quality. The Quaternary aquifer represents the most promising water bearing formation in the study area. Currently, it is the main source of water for the inhabitants at Wadi Qena Basin. The quality of groundwater in this aquifer is affected by variable sources of pollution. Mixing from waste water and agrochemicals, due to urbanization and agricultural activities, is the main pollution sources detected by Fathy et al., (2009). Ahmed et al., (2017) presented an integrated geoelectrical and hydrogeological study on Wadi Qena basin; and concluded that; the groundwater in the study area is unsuitable for drinking and other domestic uses and could be used for irrigation and some industrial activities under certain precautions. This study represents an assessment for groundwater quality of the Quaternary aquifer in Qena Basin to obtain optimal results help in groundwater management in this basin. Two effective techniques are used to develop the groundwater quality assessment in the concerned aquifer; Groundwater Quality Information Mapping and Water Quality Index Estimation and mapping.

The present study used GIS as a helpful tool that provides a good integration of various data bases (attribute data base and spatial data base) for the studied aquifer. Several studies have used GIS as a data base system in order to obtain maps of water quality according to concentration values of different 
Morsy, S. M.

chemical constituents such as Skubon, 2005; Yammani, 2007, Balakrishnan et al., 2011. WQI estimation and mapping technique is used to assess the suitability of groundwater for human consumption. It is initially proposed by Horton (1965) and Brown et al, (1970), then many different methods for the WQI's calculation have been developed by Debels et al., 2005; Saeedi et al., 2009; Tsegaye et al., 2006 and others. The main objectives of this study are: (1) to cast light on the hydrogeological sitting of the aquifer, (2) to assess the physicochemical characteristics of the groundwater and generate Water Quality Information map, (3) to obtain Water Quality Index (WQI) map, and (4) to discuss the effects of each water quality parameter on the WQI values.

\section{STUDY AREA}

The area of study occupies the southern part of Wadi Qena Basin (Fig. 1). Many previous studies have investigated the geomorphological, geological, and hydrologic features of the Wadi Qena. Aggour (1997) described the geomorphologic and geologic conditions of the wadi. Elewa et al. (2000) described the landforms of Wadi Qena basin. Based on the topographic, geologic maps, DEM and Landsat images besides field observations; Hussien, (2017) subdivided the area of study into two main landforms as shown in figure 2. Geology of the area has been studied by many authors among them are Said (1962, 1971, 1990), Ahmed (1983), El-,Shamy (1988), El-Hussaini et al. (1994), Abu El-Ella (2004), Galal (2005) Elewa et al. (2006), Elmalt (2008), , Abdel Gowad (2010), Seleem et al. (2013), Seleem (2014) and Abdel Moneim (2014). Based on the literatures; the lithostratigraphic succession of the study area ranges in age from Precambrian to Quaternary. Figure 3 shows the rock units and geologic formations along the area of Wadi Qena Basin. According to Aggour 1997 and RIGW 1998; the Quaternary alluvial deposits in the study area are formed of sand, gravel, and boulders filling the courses of the hydrographic drainage network. These sediments have great potentiality to store and transmit great amounts of groundwater. These deposits consist of the weathering products of the Cretaceous and Tertiary rocks. They have lateral and vertical variations in the lithological composition according to the dominated rock exposures through the hydrographic basins. The thickness of the Quaternary alluvial deposits varies laterally across Wadi Qena stream because of the undulation of subsurface strata and differential erosion of the surface layers. The thickness of these deposits generally decreases toward the Red Sea Mountains and increase toward the Nile Valley. Generally, the thickness is increasing downstream of the wadi, where it exceeds $100 \mathrm{~m}$. The Quaternary aquifer in the study area is recharged directly through the infiltration of the local precipitation as well as the upward leakage of groundwater from the deep Nubia sandstone aquifer through the deep seated NW-SE faults which act as conduits for groundwater as shown in figure (4). Elewa et al., (2000) and Elewa and Abu El-Ella (2011) indicated the hydraulic connection between the Quaternary aquifer and the underlying Nubian aquifer system in Wadi Qena through the structural region.

Fig. 1: Location map of the study area showing the distribution of water samples from Quaternary aquifer in Wadi Qena basin.

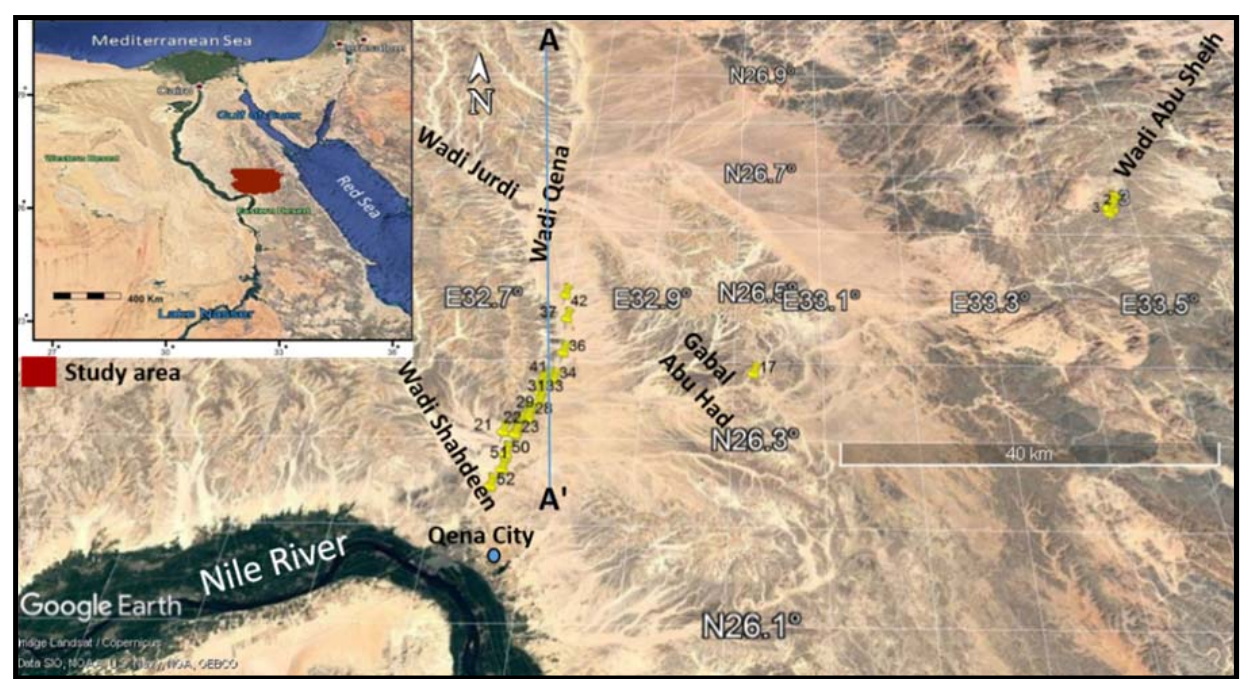


Hydrographical modelling for potentiality of water harvesting

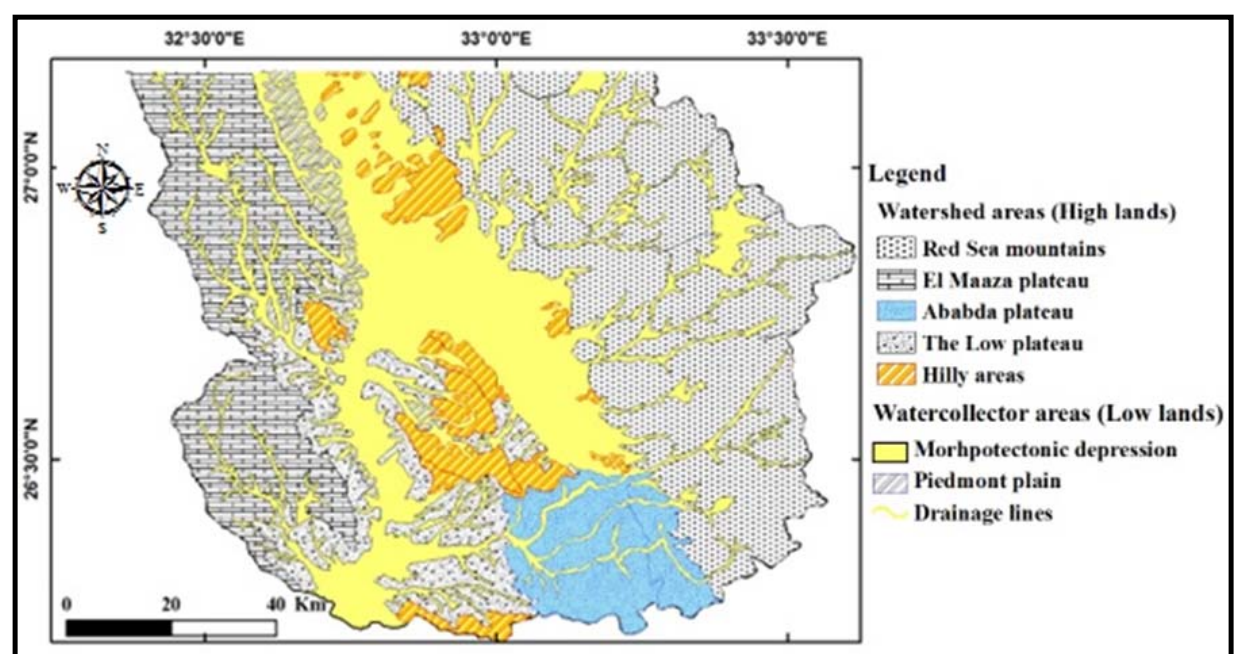

Fig. 2: Geomorphologic map of Wadi Qena Basin, Easter Desert, Egypt. (After Hussien, 2017).

Fig. 3: Geologic map of the study area (After Conoco, 1987).

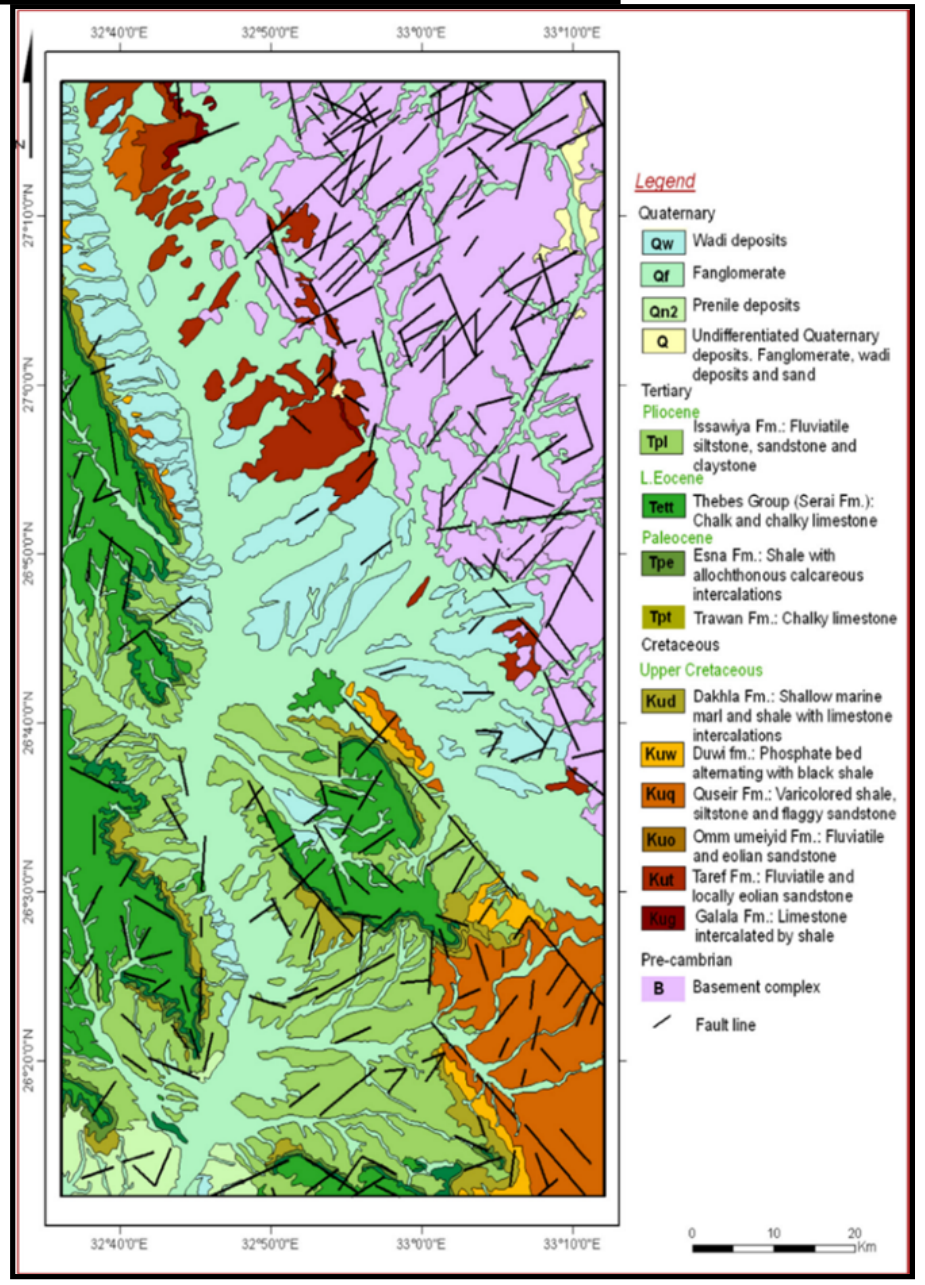

\section{METHODOLOGY}

Groundwater levels in twenty- three wells penetrating the Quaternary aquifer in the study area were measured using a suitable water level meter (See fig.1). Groundwater samples were collected from these wells and analyzed for physico-chemical parameters following US Environmental Protection Agency, 1997 (USEPA) method 300.1. The anions $\left(\mathrm{SO}_{4}^{2-}, \mathrm{Cl}^{-}\right)$and cations $\left(\mathrm{Na}^{+}, \mathrm{K}^{+}, \mathrm{Mg}^{2+}, \mathrm{Ca}^{2+}\right)$ concentrations were measured by Dionex Ion Chromatograph (Model: ICS 1100). While, carbonate and bicarbonate $\left(\mathrm{HCO}_{3}{ }^{-}, \mathrm{CO}_{3}{ }^{2-}\right)$ were determined by titration using sulfuric acid according to the methods of Rainwater 
Morsy, S. M.

and Thatcher (1960) as well as Fishman and Friedman (1985). The measurements were conducted at the laboratories of Hydrogeochemistry Department, Desert Research Center, Cairo, Egypt.

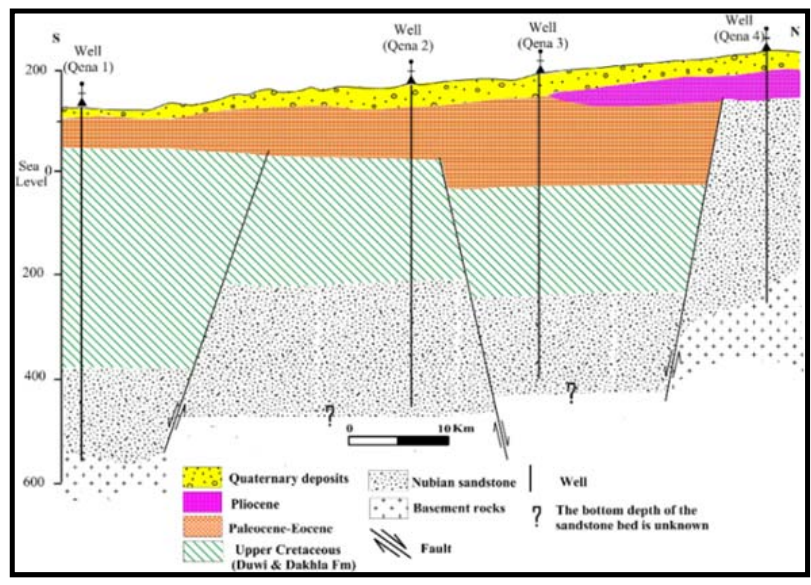

Fig. 4: N-S Geologic crosssection along traverse $\mathrm{A}-\mathrm{A}^{\prime}$ in Fig. (1). (Modified after Garpad, 1985)

Methodology used in this study is summarized in the flow chart as shown in figure 5. Two techniques were used to assess the groundwater quality of the concerned aquifer for drinking and human consumptions; Groundwater Quality Information Mapping and Water Quality Index Estimation and mapping.

Fig. 5: Flowchart showing the main materials, techniques, tools and methods used in this study.

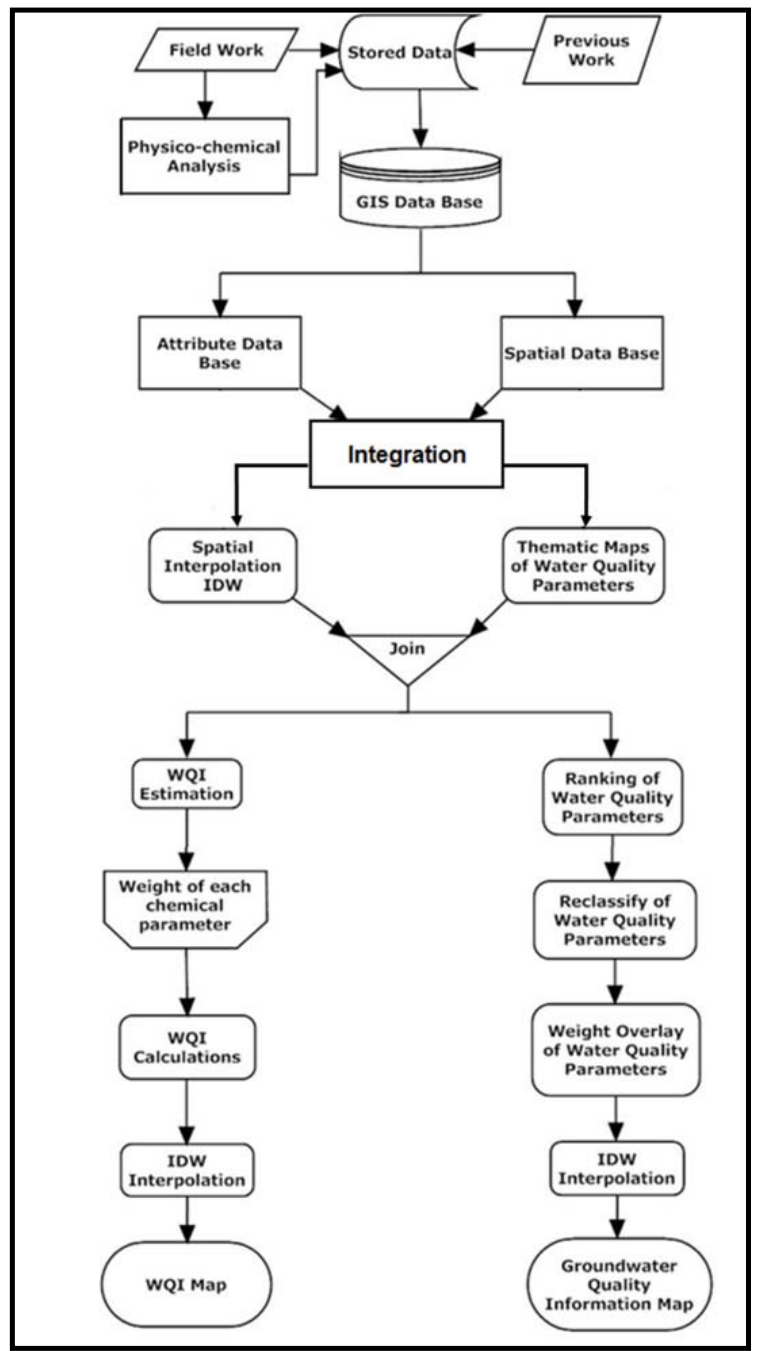

24 
Hydrographical modelling for potentiality of water harvesting

\section{Groundwater Quality Information Mapping}

This technique is used to delineate the spatial variations of groundwater quality in the study area for different purposes and classify the groundwater into three zones Potable, Permissible and Non-potable zone; as the following:

i. Spatial distribution thematic maps of water quality parameters TDS, $\mathrm{TH}$ and $\mathrm{Cl}^{-}$(Skubon, 2005; Yammani, 2007, Balakrishnan et al., 2011) are obtained by integration of attribute data base (water quality data) and spatial data base in Arc GIS software.

i. Inverse Distance Weighted (IDW) method in GIS tools is used to delineate the spatial interpolation of groundwater pollutants.

ii. Based on WHO (1996 b, 2004 and 2011) standards for water quality, each water quality parameter is ranked according to its criteria for suitability and non-suitability (table 1).

iii. A reclassified thematic map is produced for each water quality parameter according to its ranking criteria.

iv. Arc GIS Spatial Analyst extension is used to weight overlay the reclassified thematic maps by weights; $40 \% \mathrm{TDS}, 30 \% \mathrm{Cl}^{-}$and $30 \% \mathrm{TH}$ and finally obtain spatial integration for groundwater quality zone (Potable, Permissible and Non- Potable) map for drinking purposes. Total hardness $(T H)$ and sodium adsorption ratio (SAR) of groundwater samples were calculated according to Todd (1980).

v. GIS spatial interpolation technique with Inverse Distance Weighted (IDW) method is used to generate spatial distribution groundwater quality information map for drinking based on TDS classification after WHO (2011) and Davis and De Wiest (1966) (Table 2)

vi. The groundwater quality map for irrigation purposes is generated by equal $(50 \%)$ weight overlay of the reclassified thematic maps of TDS and SAR.

\section{Water Quality Index Estimation (WQI) and Mapping}

This technique is used to assess the suitability of groundwater in the study area for human consumption. The WQI in this study is calculated following the method described; Sahu and Sikdar (2008), Raychaudhuri et al., (2014), Asadi et al., (2007) and Pradhan et al., (2001) as following:

Each of chemical parameters ( $\mathrm{pH}, \mathrm{TDS}, \mathrm{TH}, \mathrm{CL}^{-}, \mathrm{SO}_{4}{ }^{2-}, \mathrm{HCO}_{3}{ }^{-}, \mathrm{Na}^{+}, \mathrm{Ca}^{+2}, \mathrm{Mg}^{+2}, \mathrm{~K}^{+}$) has been weighted (wi) from 1 to 5 according to its environmental and healthy effect (Table 3) (Dwivedi and Pathak, 2007, Srinivasamoorthy et al., 2008 and Mouna et al., 2011).

Table 1: Criteria for acceptability of water quality parameters based on WHO (2011)

\begin{tabular}{|l|l|l|l|}
\hline Parameter & Rank & Criteria & Acceptability \\
\hline TDS & 1 & $<500$ & Desired \\
& 2 & $500-1000$ & Acceptable \\
& 3 & $>1000$ & Not Acceptable \\
TH & 1 & $<500$ & Desired \\
& 2 & $500-1000$ & Acceptable \\
& 3 & $>1000$ & Not Acceptable \\
& & \\
$\mathbf{C l}^{-}$ & 1 & $<250$ & Desired \\
& 2 & $250-1000$ & Acceptable \\
& 3 & $>1000$ & Not Acceptable \\
\hline
\end{tabular}

Table 2: Groundwater classification according to Davis and De Wiest, 1996.

\begin{tabular}{|l|l|}
\hline Water Type & Concentration of dissolved constituent ppm) \\
\hline Fresh Water & $0-1,000$ \\
\hline Brackish Water & $1,000-10,000$ \\
\hline Saline Water & $10,000-100,000$ \\
\hline Brine Water & $>100,000$ \\
\hline
\end{tabular}


Morsy, S. M.

Table 3: Water quality parameters, WHO standards and assigned unit weights

\begin{tabular}{lccc}
\hline \multicolumn{1}{c}{ Chemical parameter } & WHO standard & Weight $\left(\mathbf{w}_{\mathbf{i}}\right)$ & Relative weight $(\mathbf{W I})$ \\
\hline $\mathrm{pH}$ & 8.5 & 3 & 0.107143 \\
\hline $\mathrm{TDS}(\mathrm{mg} / \mathrm{l})$ & 500 & 5 & 0.178571 \\
\hline $\mathrm{Cl}(\mathrm{mg} / \mathrm{l})$ & 250 & 3 & 0.107143 \\
\hline $\mathrm{TH}$ & 300 & 4 & 0.142857 \\
\hline $\mathrm{SO}_{4}^{-2}(\mathrm{mg} / \mathrm{l})$ & 250 & 3 & 0.107143 \\
\hline $\mathrm{HCO}_{3}^{-}(\mathrm{mg} / \mathrm{l})$ & 120 & 2 & 0.071429 \\
\hline $\mathrm{Na}^{+}(\mathrm{mg} / \mathrm{l})$ & 200 & 3 & 0.107143 \\
\hline $\mathrm{Ca}^{2+}(\mathrm{mg} / \mathrm{l})$ & 75 & 2 & 0.071429 \\
\hline $\mathrm{Mg}^{2+}(\mathrm{mg} / \mathrm{l})$ & 50 & 2 & 0.071429 \\
\hline $\mathrm{K}^{+}(\mathrm{mg} / \mathrm{l})$ & 12 & 1 & 0.035714 \\
\hline & & $\sum \mathrm{w}_{\mathrm{i}}=28$ & $\sum \mathrm{WI}=1$ \\
\hline
\end{tabular}

i. WQI is calculated by applying equations [1-4]:

The relative weight: $\mathrm{WI}=\frac{w i}{\sum_{i=1}^{n} w i}$

The quality rating: $q i=\frac{C i}{S i} \times 100$

$\boldsymbol{C} \boldsymbol{i}$ is the concentration of each chemical parameter in each water sample in $\mathrm{mg} / \mathrm{l}$

$\boldsymbol{S i}$ is the WHO standard for each chemical parameter in $\mathrm{mg} / \mathrm{l}$.

$S I i=\mathrm{WI} \times q i$

$\mathrm{WQI}=\sum S I i$

ii. WQI values are classified into five classes according to the type of water (Sahu and Sikdar, 2008) for human consumption (Table 4).

iii. GIS spatial interpolation technique with Inverse Distance Weighted (IDW) method is used to obtain WQI spatial distribution map.

Table 4: WQI values classification (Sahu and Sikdar, 2008)

\begin{tabular}{|c|c|}
\hline WQI Value & Water Quality \\
\hline$<50$ & Excellent \\
\hline $50-100$ & Good \\
\hline $100-200$ & Poor \\
\hline $200-300$ & Very Poor \\
\hline$>300$ & Unfit for human consumption \\
\hline
\end{tabular}

\section{RESULTS AND DISCUSSIONS}

The results of field measurements and phsico-chemical analysis for the collected groundwater samples are shown in table 5. The Quaternary aquifer in the study area is characterized by unconfined conditions and the depth to water from ground surface ranges from $2.7 \mathrm{~m} \mathrm{(msl)} \mathrm{(at} \mathrm{well} \mathrm{no.2 \& 3)} \mathrm{to} 35.95 \mathrm{~m}$ (msl) (at well no. 51). The water table map of the concerned aquifer (Fig. 6) shows recharge area at the northeastern part of study area; this is attributed to the presence of recharge sources from the upward flow from Nubia sandstone aquifer through NW-SE faults and fractured basement rocks as well as the surface recharge from the upstream courses of wadies of alluvium deposits. So the flow direction of groundwater in this aquifer is defined from the northeast to southwest. A second direction of flow is from north to south direction due to excessive pumping for irrigation activities at the south part of the studied area, where the estimated discharge from shallow dug wells and open pits reaches $107 \mathrm{~m}^{3} /$ hour and the total drawdown after 4 hours pumping reaches $1.22 \mathrm{~m}$ (EDP, 2006). 
Hydrographical modelling for potentiality of water harvesting

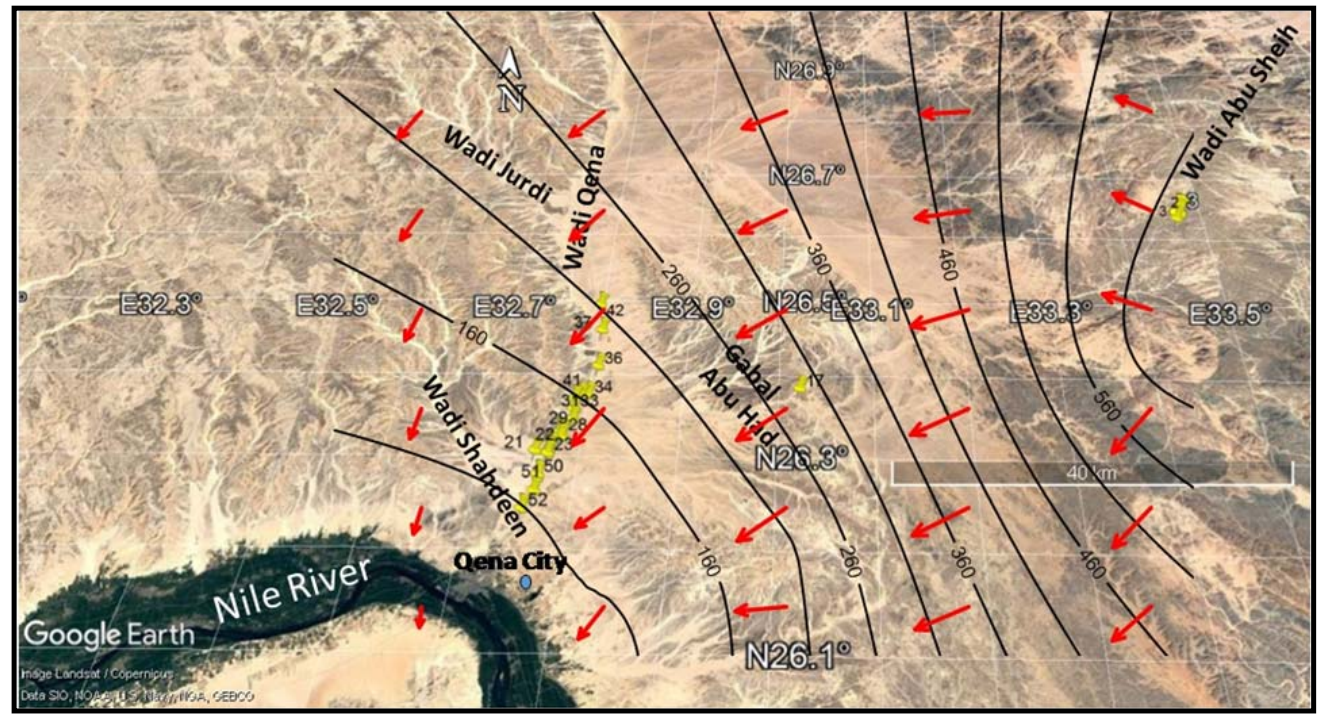

Fig.6: Water table map for the Quaternary alluvium aquifer at Wadi Qena basin, Eastern Desert Egypt.

\section{Groundwater Quality Assessment}

\section{i. Evaluation of Groundwater for Drinking}

The total dissolved solids (TDS) of groundwater in the concerned aquifer comprise inorganic salts (principally calcium, magnesium, potassium, sodium, bicarbonates, chlorides and sulfates). The concentrations of TDS in water vary considerably from locality to another locality owing to differences in the solubility of minerals forming the water- bearing formations. Where the TDS values vary greatly between $587 \mathrm{mg} / \mathrm{l}$ at well no. 2 to $36507 \mathrm{mg} / \mathrm{l}$ at well no. 34 . The low salinity values are attributed to the replenishment from fresh groundwater recharge sources at the eastern part of the study area. The high salinity values are attributed to dissolving processes of natural salts present in the host sediments and soil in addition to recycling and leaching through irrigation. Based on Davis and Dewiest classification (1996), three main types of groundwater which are; fresh, brackish and saline waters are recorded in the studied water samples (Fig. 7).

Fig.7: TDS Spatial distribution based on Davis and Dewiest classification (1996)

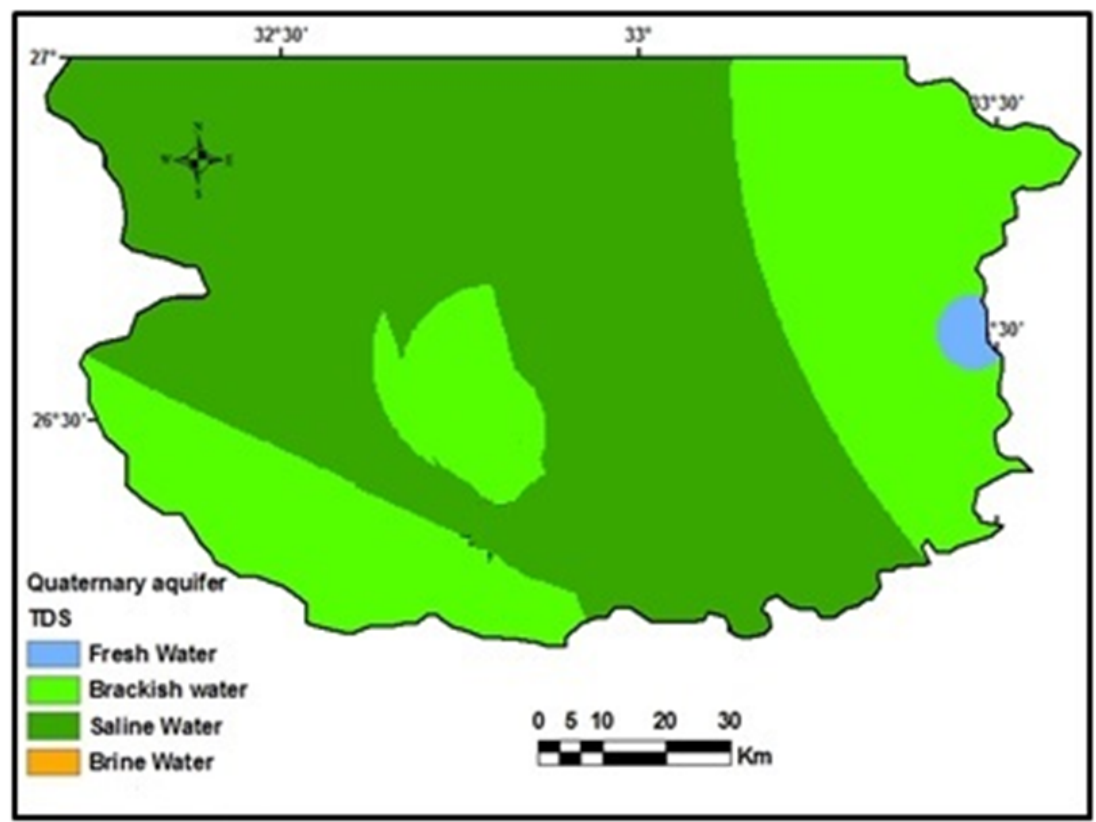


Morsy, S. M.

Table 5: Values of various physico-chemical parameters for groundwater samples, of the Quaternary aquifer, in Wadi Qena basin.

\begin{tabular}{|c|c|c|c|c|c|c|c|c|c|c|c|c|c|c|}
\hline 34 & 112 & 36507 & 16520.28 & 3939.47 & 1627.22 & 7442.45 & 80.66 & 0 & 56 & 2851.08 & 20510.5 & 7.71 & 38400 & 25.18 \\
\hline 35 & 116 & 4917 & 1836.138 & 501.28 & 142.18 & 950.48 & 21.3 & 0 & 79.33 & 1377.84 & 1844.12 & 8.11 & 6160 & 9.65 \\
\hline Well No. & $\begin{array}{c}\text { Water } \\
\text { Level } \\
\text { (m amsL) }\end{array}$ & $\underset{\mathrm{mg} / 1}{\mathrm{TDS}}$ & $\underset{\mathrm{mg} / 1}{\mathrm{TH}}$ & $\underset{\mathrm{mg} / 1}{\mathrm{Ca}^{++}}$ & $\underset{\mathrm{mg} / 1}{\mathrm{Mg}^{++}}$ & $\underset{\mathrm{mg} / 1}{\mathrm{Na}^{+}}$ & $\underset{\mathrm{m} g / 1}{\mathrm{~K}^{+}}$ & $\mathrm{CO}_{\mathrm{m} / 1}^{--}$ & $\underset{\mathrm{mg} / 1}{\mathrm{HCO}_{3}^{-}}$ & $\underset{\mathrm{mg} / 1}{\mathrm{SO}_{4}^{-}}$ & $\underset{\mathrm{m} g / 1}{\mathrm{CL}^{-}}$ & $\mathrm{pH}$ & $\begin{array}{c}\text { E.C } \\
\mu \mathrm{Mhos} / \mathrm{cm}\end{array}$ & SAR \\
\hline 2 & 648.3 & 587 & 78.185 & 22.91 & 5.1 & 133.54 & 3.58 & 9.18 & 302.99 & 74.65 & 34.75 & 8.69 & 610 & 6.57 \\
\hline 3 & 647.1 & 598 & 67.353 & 20.25 & 4.08 & 150.62 & 1.5 & 4.59 & 312.66 & 75.11 & 29.18 & 8.75 & 672 & 7.98 \\
\hline 17 & 195.82 & 32432 & 2282.254 & 575.16 & 205.94 & 9322.53 & 131.13 & 0 & 177.33 & 20138.98 & 1881.11 & 8.39 & 27670 & 84.86 \\
\hline 21 & 75 & 5765 & 2234.723 & 587.57 & 186.78 & 1122.04 & 27.19 & 0 & 112 & 1870.79 & 1858.9 & 8.3 & 7160 & 1032 \\
\hline 22 & 71.86 & 5163 & 1781.805 & 490.83 & 135.3 & 1084.92 & 18.58 & 0 & 88.66 & 1656.18 & 1688.9 & 8.23 & 6610 & 11.18 \\
\hline 23 & & 6009 & 2229.149 & 595 & 180.89 & 1227.25 & 42.72 & 0 & 84 & 1976.38 & 1902.31 & 8.17 & 6780 & 11.3 \\
\hline 24 & & 7653 & 2819.917 & 781.32 & 211.37 & 1485.91 & 20.47 & 9.18 & 112 & 2365.67 & 2667.42 & 8.14 & 9440 & 12.17 \\
\hline 25 & & 9194 & 3517.95 & 971.35 & 265.75 & 1742.67 & 26.53 & 0 & 121.33 & 2659.38 & 3407.46 & 8.15 & 10950 & 12.78 \\
\hline 26 & 74.07 & 7683 & 2915.341 & 806.96 & 219.01 & 1499.45 & 25.41 & 0 & 107.33 & 2371.02 & 2653.62 & 8.18 & 9610 & 12.08 \\
\hline 28 & 106 & 17076 & 6655.5 & 1769.22 & 544.5 & 3400.32 & 54.86 & 0 & 121.33 & 2403.03 & 8783.15 & 7.94 & 21640 & 18.13 \\
\hline 29 & 98.5 & 6619 & 2504.502 & 676.31 & 198.47 & 1333.64 & 31.63 & 0 & 74.66 & 1859.56 & 2444.77 & 8.1 & 8260 & 11.59 \\
\hline 30 & 102 & 11515 & 5619.346 & 1680.2 & 346.06 & 1773.07 & 35.45 & 0 & 56 & 2269.51 & 5355.17 & 7.88 & 14420 & 10.29 \\
\hline 31 & 11 & 10329 & 4089.717 & 1195.35 & 268.62 & 2007.98 & 29.97 & 0 & 74.66 & 1907.56 & 4845.13 & 7.97 & 13600 & 13.66 \\
\hline 33 & 108 & 10072 & 3936.212 & 1106.15 & 285.57 & 1903.86 & 30.5 & 0 & 195.99 & 2454.85 & 4095.1 & 7.62 & 12640 & 13.2 \\
\hline 36 & 124 & 4029 & 1712.31 & 474.84 & 128.1 & 677.58 & 16.34 & 0 & 93.33 & 1201.56 & 1437.15 & 7.74 & 5050 & 7.12 \\
\hline 37 & 132 & 5948 & 2676.669 & 779.42 & 177.59 & 943.32 & 18.15 & 0 & 167.99 & 1687.65 & 2173.48 & 7.58 & 7270 & 7.93 \\
\hline 41 & 115.8 & 7228 & 2707.473 & 774.21 & 188.28 & 1422.8 & 20.11 & 0 & 93.33 & 1597.34 & 3131.9 & 7.61 & 9190 & 11.89 \\
\hline 42 & 133 & 6918 & 2843.4 & 795.83 & 208.25 & 1208.35 & 25.53 & 0 & 65.33 & 2172.54 & 2442.29 & 7.29 & 8350 & 9.86 \\
\hline 50 & 72.44 & 6138 & 2463.283 & 595.19 & 237.88 & 1130.81 & 32.76 & 0 & 65.33 & 1966.72 & 2109.33 & 7.94 & 7690 & 9.91 \\
\hline 51 & 69.85 & 10315 & 3162.529 & 787.46 & 291.19 & 2218.24 & 62.09 & 0 & 167.99 & 3307.58 & 3480.77 & 7.86 & 12170 & 17.15 \\
\hline 52 & & 8984 & 2383.634 & 588.16 & 222.74 & 2190.8 & 21.07 & 0 & 121.33 & 2032.47 & 3807.44 & 7.69 & 11440 & 19.51 \\
\hline
\end{tabular}




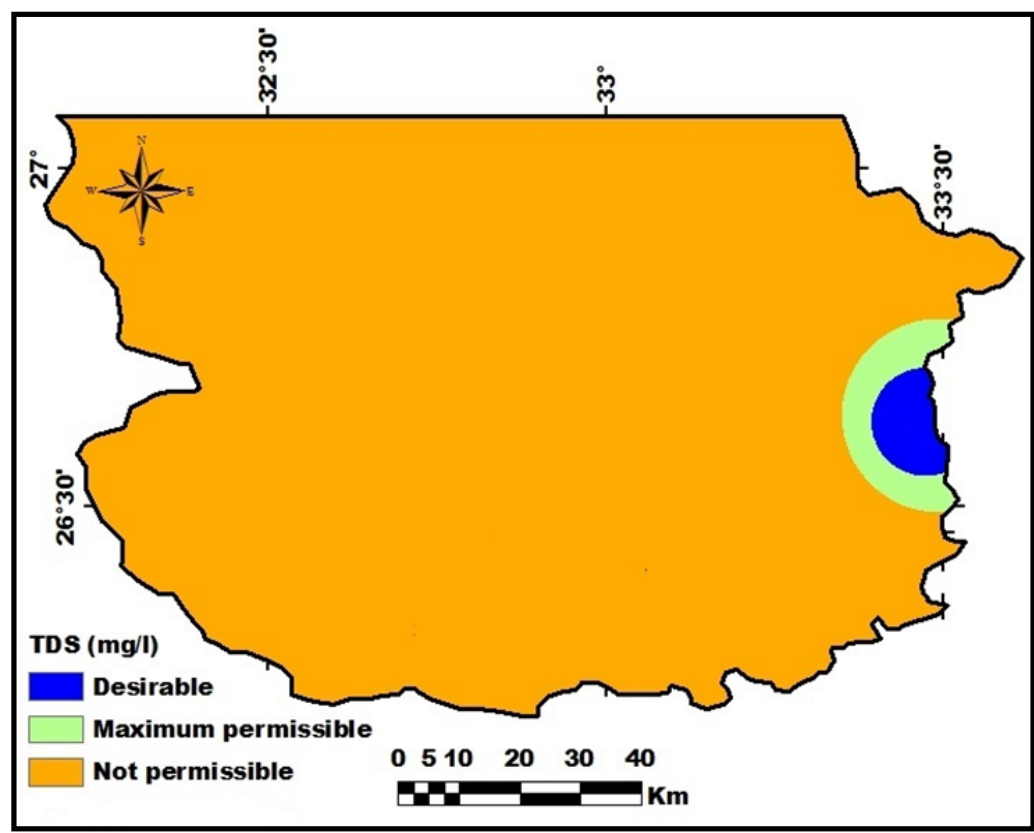

Fig. 8: TDS spatial distribution map for drinking in the study area according to $\mathrm{WHO}$ (2011).

Fig. 9: Groundwater Quality Information Map for drinking in the study area.

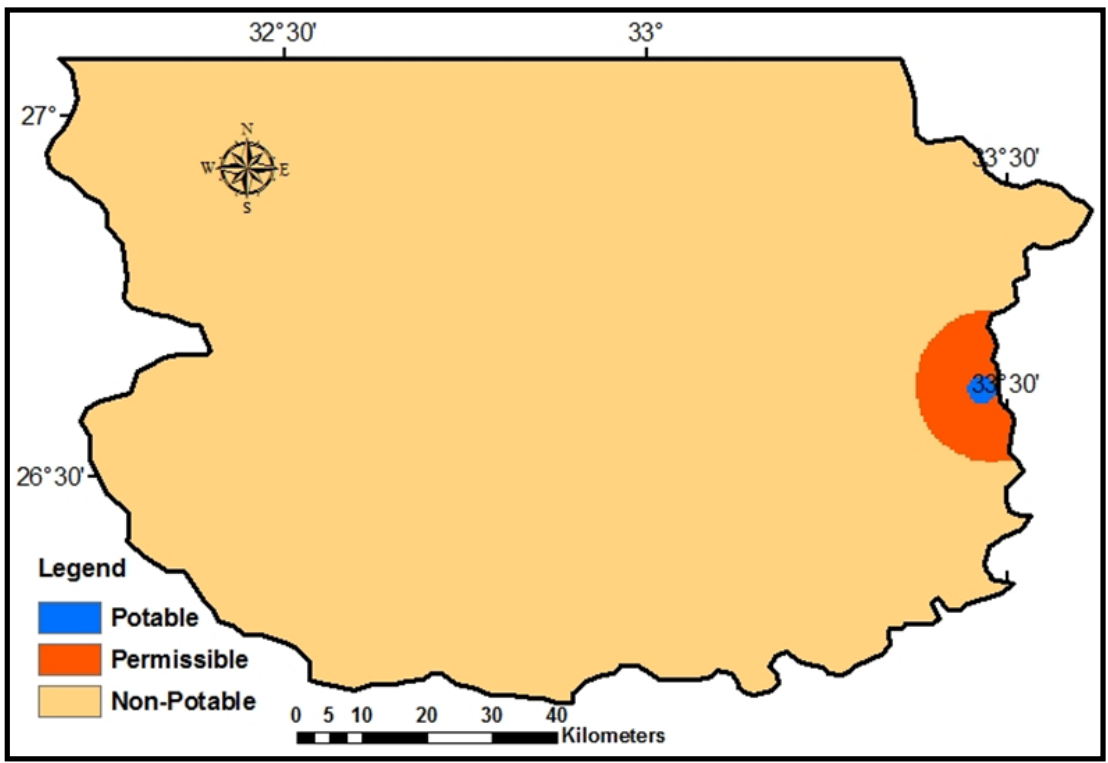

\section{ii. Evaluation of groundwater for livestock and poultry}

The National Academy of Science NAS (1972) put the principle criteria for evaluation of the water for livestock depending on the concentration of total dissolved solids (Table 6). The concentrations should not exceed 5,000 ppm as far as possible. However, the animals can drink water with moderately high dissolved solids (about $10000 \mathrm{ppm}$ ) when $\mathrm{Na} \mathrm{Cl}$ is the main constituent. Figure (10) shows the spatial distribution of TDS in the study area based on NAS, 1972 classification. It is obvious that the majority of groundwater in the studied aquifer belongs to class 6 . Relatively lower salinity is found at the western part of the study area. Gradual decreasing in groundwater salinity occurs to the east direction of the study area results in different groundwater characters for different uses.

The TDS spatial distribution map for drinking purposes in the study area according to WHO (2011) (Fig. 8) shows that almost all the groundwater in the area exceed the permissible limit and unsuitable for drinking except at the eastern part of the study area.

As a result of the Water Quality Information mapping technique; the obtained Water Quality Information map (Fig. 9) detected that the groundwater in the study area is Non-potable except at the eastern part of the wadi where the groundwater ranges from permissible to potable. 


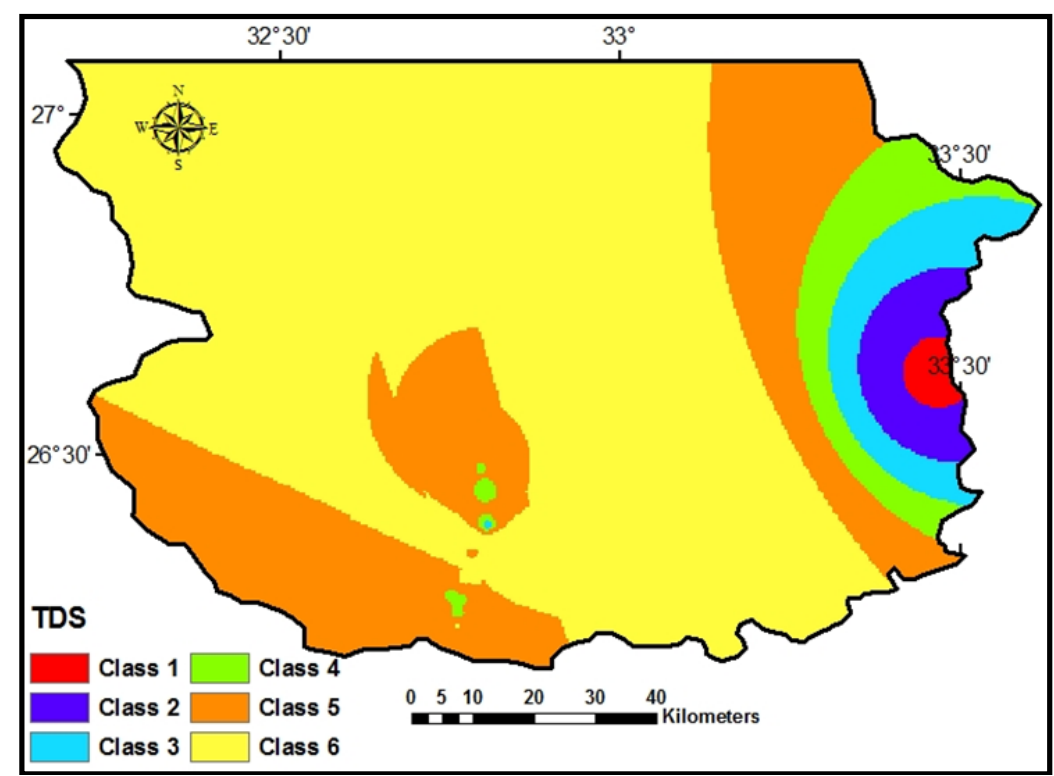

Fig.10: Groundwater quality map for livestock and poultry in the study area based on NAS, 1972 Classification.

\section{iii. Evaluation of groundwater for irrigation}

Based on the groundwater quality mapping technique; Groundwater Quality map for irrigation purposes by equal weighting of TDS and SAR is obtained (Fig. 11). It reflects that most of the groundwater in the study area has excessive salinity and undesirable ion exchange. Except some scattered small areas located at the eastern and western parts are of good groundwater characters.

Table 6: Classification of groundwater for livestock and poultry (National Academy of Science, NAS 1972).

\begin{tabular}{|l|l|l|}
\hline \multicolumn{1}{|c|}{ Class } & \multicolumn{1}{|c|}{ Concentration (TDS) } & \multicolumn{1}{c|}{ Characters } \\
\hline 1 & $<1,000$ & Excellent for all classes of livestock and poultry \\
\hline 2 & $1,000-2,999$ & Very satisfactory for all classes of livestock and poultry. \\
\hline 3 & $3,000-4,999$ & Satisfactory for livestock \\
\hline 4 & $5,000-6,999$ & Can be used with reasonable safety \\
\hline 5 & $7.000-10,000$ & Unfit for poultry and probably for swine \\
\hline 6 & $>10,000$ & Not recommended for use under any conditions \\
\hline
\end{tabular}

Fig.11: Groundwater Quality map for irrigation purposes by Equal Weighting of TDS and SAR.

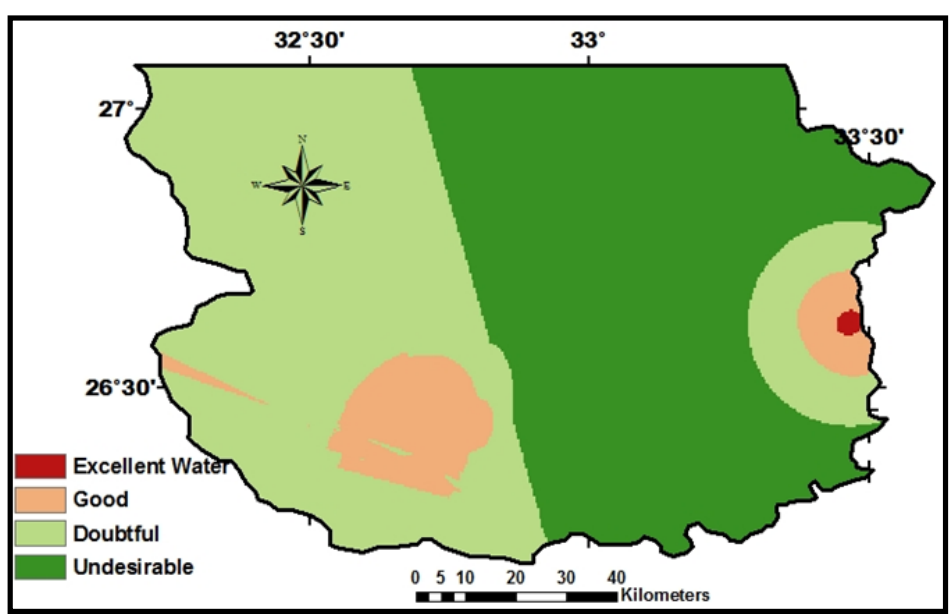

CONCLOUSION

The present study introduces a new sight for the groundwater quality of the Quaternary aquifer in Wadi Qena Basin, Eastern Desert, Egypt. Two effective techniques are carried out to assess the groundwater quality in the concerned aquifer which are; Groundwater Quality Information Mapping technique and Water Quality Index Estimation and mapping technique. 


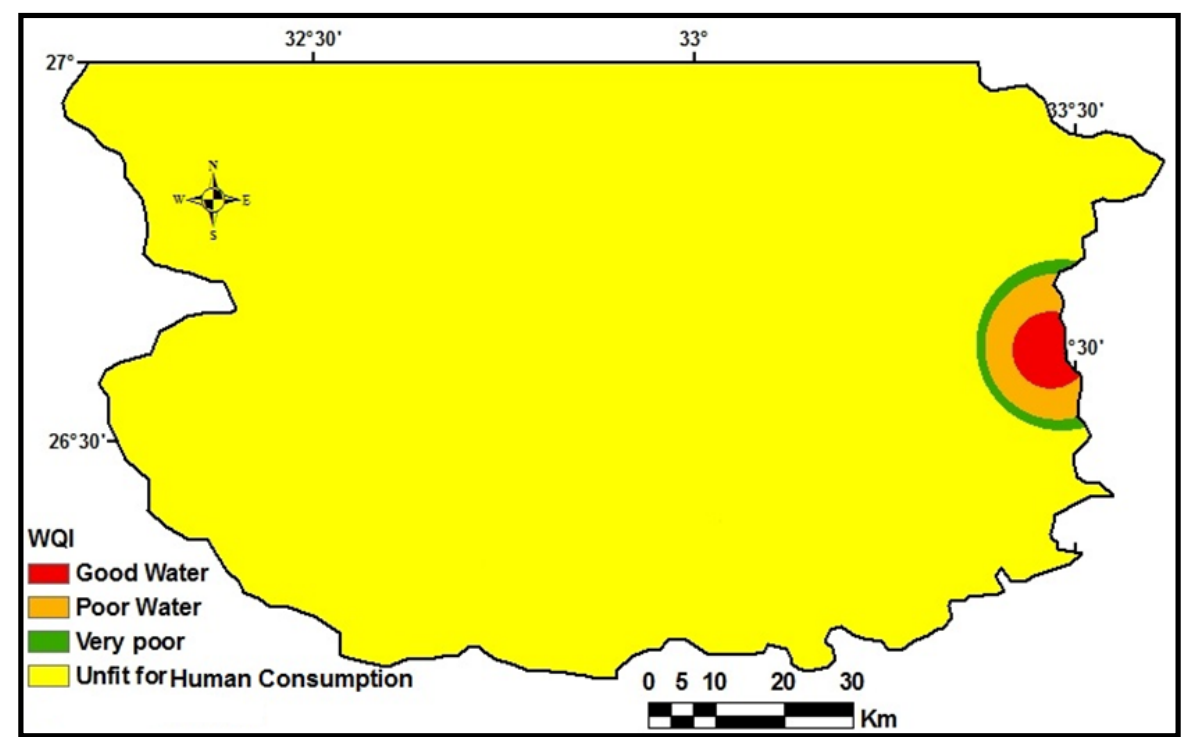

Fig.12: Water Quality Index map in the study area.

The GIS is used as a helpful tool to integrate, analyze and display of both attribute data base (nonspatial) and spatial data base of the study area. The resultant maps from the applied techniques revealed that, the groundwater in the eastern portion of the studied aquifer exists in the Potable zone and is suitable for human consumption. This is mainly attributed to the direct replenishment from the nearby watershed area and the lithologic composition of the parent rocks which are formed mainly of granite as well as its closeness to recharge sources from the fractured basement rocks and the Nubia sandstone water through NW-SE deep seated faults. The best sites for groundwater extractions from the Quaternary aquifer in Wadi Qena Basin are detected at the eastern side of the study area. At the western portion of the concerned aquifer; the groundwater exists in the Not-potable zone, and Un-fit for human consumption, while it is suitable for irrigation, livestock and poultry purposes under certain constraints. High evaporation intensity of shallow groundwater, continuous withdrawing of the water play an effective role in the groundwater degradation in the study area. At the downstream portion of Wadi Qena the total salinity is very high due to high leaching from the gypsferous and saliferous shales in addition to the excessive extraction from the aquifer for different human purposes. Continuous monitoring and earnest groundwater quality management are necessary for the present status of groundwater in the study area.

\section{REFERENCES}

Abdel Gowad, A.M. (2010): Geophysical Studies of Wadi El-Serai Area on the Desert Road of QenaLuxor, Eastern Desert, Egypt. M. Sc. Thesis, Faculty of Science, South Valley Univ., Egypt.

Abdel Moneim, A. A. (2014): Hydrogeological conditions and aquifers potentiality for sustainable development of the desert areas in Wadi Qena, Eastern Desert, Egypt. Arab. J. Geosci. 7 (11), 4573 $-4591$.

Abu El-Ella, K. A. A. (2004): Study of the Recent Sediments for some Wadis in Qena Governorate and their Role in the Development. M. Sc thesis, Faculty of Science, South Valley Univ., 253p.

Aggour, T. A. (1997): Impact of geomorphological and geological setting on groundwater in QenaSafaga District, Central Eastern Desert, Egypt. Ph.D. Thesis, Fac. Sci., Ain Shams Univ., 355p.

Ahmed, E. A. (1983): Sedimentology and Tectonic Evolution of Wadi Qena Area, Egypt. Ph. D thesis, Geology Dept., Assuit University, 136 p.

Ahmed, G., Hassan, M., Nahed, A. and Mostafa, G. (2017): Integrated geoelectrical and hydrogeological studies on Wadi Qena, Egypt. NRIAG Journal of Astronomy and Geophysics 6 (2017) 218-229

Asadi, S.S., P. Vuppala and M. Anji Reddy (2007): Remote Sensing and GIS Techniques for Evaluation of Groundwater Quality in Municipal Corporation of Hyderabad (Zone-V), India. Int. J. Environ. Res. Public Health, 4(1): 45-52.

Balakrishnan, P., Abdul Saleem and Mallikarjun, N. D. (2011): African Journal of Environmental Science and Technology Vol. 5(12), pp. 1069-1084.

Brown, R. M., McClelland, N. I., Deininger, R. A., Tozer, R. G. (1970): A water quality index - do we dare? Water Sew. Works 117, 339-343. 
Morsy, S. M.

Conoco (1987): Geological map of Egypt, Scale 1:500,000, Sheet NG36NW Quseir-

Davis S. N. and De Wiest R. J. (1966): Hydrogeology, New York: Wiley.

Debels, P., Figueroa, R., Urrutia, R., Barra, R., Niell, X. (2005): Evaluation of water quality in the Chilla'n river (Central Chile) using physicochemical parameters and a modified water quality index. Environ. Monit. Assess. 110, 301-322.

Dwivedi, S. L. and Pathak, V. (2007): A preliminary assignment of water quality index to Mandakini River, Chitrakoot. Indian J. Environ. Protection, (27): 1036-1038.

Eastern Desert Project (EDP) (2006): Developing renewable ground water resources in arid lands pilot case: The Eastern Desert of Egypt, local assessment and field verification for "Wadi Qena", final Report, 220 p.

El Shamy, I. Z. (1988): Quantitative geomorphology and surface runoff control for Wadi Qena, Central Eastern Desert. E. G. S. proc. of the 6th Ann., pp. 13 - 26.

Elewa, H.H. and Abu El.-Ella, E.M. (2011): Numerical modeling for the Nubian aquifer development in Wadi Qena, Eastern Desert, Egypt. Egypt. J. Geol. 55, 105-125.

Elewa, H. H., Fathy, R. G., Zaghloul, E. A. (2000): Groundwater potential of the Southern Part of Wadi Qena Basin, Eastern Desert of Egypt Using Remote Sensing Techniques. Egypt J. Rem. Sens. Spac. Sci. 3, 135-152.

Elewa, H. H., Hassan, A. Z. A., Kotb, M. M. (2006): Possibility of the agricultural expansion based on land and water resources potentialities at the southern part of Wadi Qena, Central Eastern Desert, Egypt. Egypt. J. Soil Sci. 46 (2), 153-174.

El-Hussaini, A. H., Ibrahim, H. A., Bakheit, A. A. (1994): Interpretation of geoelectrical data from an area of the entrance of Wadi Qena, Eastern Desert, Egypt. J. King Saud Univ. 7(2), 257-276.

El-Malt, A. K. A, (2008): Paleontological and Stratigraphical Studies on the Macrofossils of some Upper Cretaceous Sections Exposed in Southern Wadi Qena and Neighboring Areas, Eastern Desert, Egypt. M. Sc., South Valley Univ., Egypt.

Fathy, A., Ayman, A., and Adly, A. (2009): Degradation of groundwater quality of quaternary aquifer at Qena, Egypt, Journal of Environmental Studies, Vol. 1: 19-32

Fishman, M. J. and Friedman, L. C. (1985): "Methods for determination of inorganic substances in water and fluvial sediments". U.S. Geol. Surv. Book 5, Chapter A1. Open File Report 85-495, Denver, Colorado, U.S.A.

Galal, W.F.H. (2005): Geological and Geophysical Studies on the Areas around Nile Bend, Qena Province, Egypt. M. Sc. Fac. Sci., Assuit Univ.

Garpad (1985): Internal Report on Wadi Qena, Groundwater Studies, First Phase. Cairo, 95 p.

Horton, R. K. (1965): An index number systemfor rating water quality. J.Water Pollut. Control Fed. 37 (3), 300-306.

Hussien, M. H. (2017): Development of the water resources in Wadi Qena Basin, Eastern Desert, Egypt. Ph.D. Thesis, Fac. Sci., Ain Shams Univ., 165 p.

Mouna, K.R., Moncef, G. and Rachida, B. (2011): Use of Geographical Information System and Water Quality Index to Assess Groundwater Quality in El Khairat Deep Aquifer (Enfidha, Tunisian Sahel), Iranica Journal of Energy \& Environment 2 (2): 133-144

National Academy of Science and National Academy of Engineering (NAS) (1972): Water quality criteria: Protection Agency, Washington, D.C., 594 p. NG36NW Asuit. The Egyptian General Petroleum Corporation, Cairo, Egypt.

Pradhan, S. K., D. Patnaik and S.P. Rout (2001): Water quality index for the groundwater in and around a phosphatic fertilizer plant. Indian J. Environ. Protection, (21): 355-358.

Rainwater, F. H. and Thatcher, L. I. (1960): "Methods for collection and analysis of water samples". U.S. Geol. Survey, Water Supply, 1454, 301p.

Raychaudhuri, M., Raychaudhuri, S., Jena, S. K., Kumar, A. and Srivastava, R. C. (2014): WQI to Monitor Water Quality for Irrigation and Potable Use. Research Bulletin No. 71, 43.

Research Institute of Groundwater (RIGW) (1998): Hydrogeological map of Wadi Qena. RIGW, Cairo.

Saeedi, M., Abessi, O., Sharifi, F., Maraji, H. (2009): Development of groundwater quality index. Environ. Monit. Assess. 163 (1-4), 327-335.

Sahu, P. and Sikdar, P. K. (2008): Hydrochemical Framework of the Aquifer in and around East Kolkata Wetlands, West Bengal, India. Environmental Geology, 55, 823-835. https://doi.org/10.1007/s00254-007-1034-x

Said, R. (1962): The Geology of Egypt. Elsevier, Amesterdam, 377 p. 
Said, R. (1971): Explanatory note to accompany the geological map of Egypt. Geol. Surv. Egypt, Internal Report 56, 123.

Said. R. (1990): The Geology of Egypt. A.A. Balkema /Rotterdam/ Brookfield, 734 p.

Seleem (2014): Hydrogeological and geoelectrical studies on some areas in Wadi Qena, Eastern Desert, Egypt. PhD thesis submitted to Faculty of Science, Sohag Univ., Egypt.

Seleem, E. M., Abdel Monem, A.A., Zeid, S.A. (2013): Geoelectrical soundings to delineate the Quaternary groundwater aquifer in the central part of Wadi Qena, Eastern Desert, Egypt. Egypt J. Appl. Geophys. 12 (2), 191-207.

Skubon, J. R. (2005): Groundwater quality and GIS investigation of a shallow sand aquifer, Oak opening region, North West Ohio. Geological Society of America. Abstracts Programs, 37(5): 94.

Srinivasamoorthy, K., M. Chidambaram, M.V. Prasanna, M. Vasanthavigar, A. John Peter and P. Anandhan (2008): Identification of major sources controlling Groundwater Chemistry from a hard rock terrain-A case study from Mettur taluk, Salem district, Tamilnadu, India. J. Earth System Sci., 117(1): 49-58.

Todd, D. K. (1980): Groundwater Hydrology. John Wiley \& Sons, New York.

Tsegaye, T., Sheppard, D., Islam, K.R., Johnson, A., Tadesse, W., Atalay, A., Marzen, L. (2006): Development of chemical index as a measure of in stream water quality in response to land use and land cover changes. Water Air Soil Pollut. 174, 161-179.

U.S. Environmental Protection Agency (1997): The Determination of Inorganic Anions in Water by Ion Chromatography, USEPA, Method 300.1, Cincinnati, OH, 1997.

World Health Organization (WHO) (1996b): Water quality monitoring: A practical guide to the design and implementation of freshwater quality studies and monitoring programs. E and FN Spon, London, UK.

World Health Organization (WHO) (2004): Guidelines for drinking water quality: training pack. Geneva, Switzerland.

World Health Organization (WHO) (2011): The guidelines for drinking- water quality, 4th ed. ISBN 978924154815 1, available on:(http://www.who.int), p 564.

Yammani, S. (2007): Groundwater quality suitable zones identification: application of GIS, Chittoor area, Andhra Pradesh, India. Environ. Geol., 53(1): 201-210. 
Morsy, S. M.

تقييم جودة العياه الجوفيه في خزان العصر الجيولوجي الرياعى، حوض وادى قنا، الصحراء الثرقية، مصر.

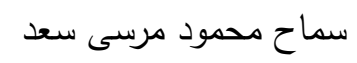

قسم الجيولوجيا - كلية العوم- -جامعة عين شمس سعد

\section{الخلاصة}

تهدف الدراسة الحالية الى نقييم جودة المياه الجوفية في خزان العصر الجيولوجى الرباعي في حوض وادي قنا،

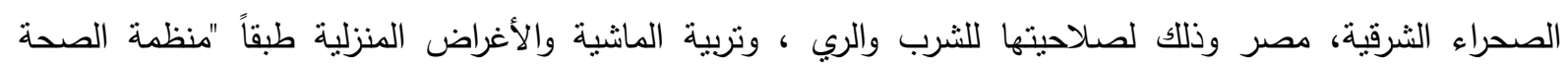

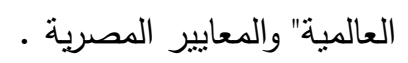

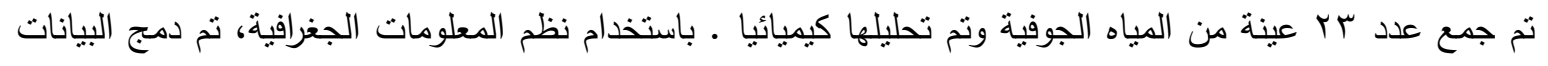

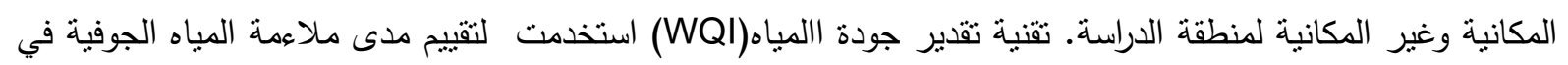

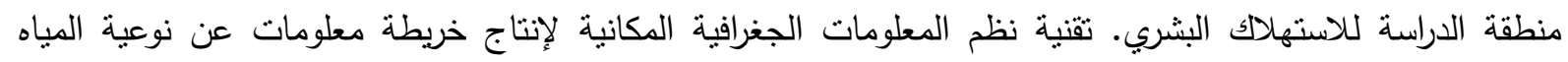
الجوفية وتوزيعاتها فى منطقة الدراسة .

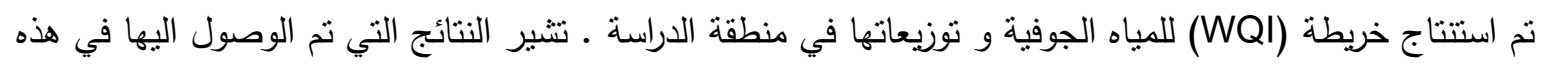

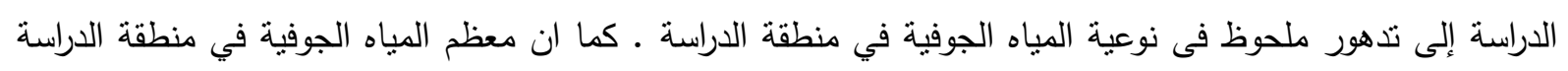

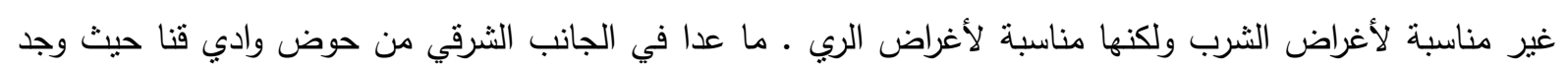

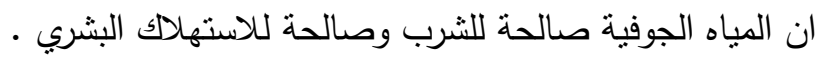


